\title{
INEQUALITIES INVOLVING TRIGONOMETRIC AND HYPERBOLIC FUNCTIONS
}

\author{
HidEFUMi KATSUURA AND SAMIH OBAID
}

Abstract. We introduce three different proofs of Priceòs inequality and some new trigonometric and hyperbolic inequalities.

Mathematics subject classification (2000): 26D05.

Key words and phrases: Priceòs inequality, trigonometric, hyperbolic, inequalities.

\section{REFERENCES}

[1] E. HiLle, Analytic Function Theory, Vol. II, Chelsea Publishing Company, New York (1962).

[2] T. E. PRICE, Product of Chord Lengths of an Ellipse, Math Magazine, 75, (4) (2002), 300-307. 